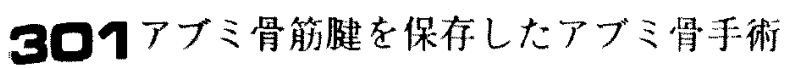

宇良政治、安田忍、真栄田松行、嘉数光推

琉球大学医学部耳睯咽喉科

耳硬化症に对する手術㞠法は聴力の著しい改尊をもたらす。その力法として、アフミ骨全体を摘出して置換するstapedectomy よりしアブミ骨上部楼造を除去して、底坂の小孔にピストンを䇴く stapedotomyがより安全な手術法として普及している。 しかしながら、そのいづ玑の方法もアブミ骨肪腱を切断する方法である。アプミ骨筋反射による強大音からの内耳の保護等 の機能は当然失われることになる。そこで、今回、アフミ骨旆琎を保存した手術を考按し、施行したので報告する。

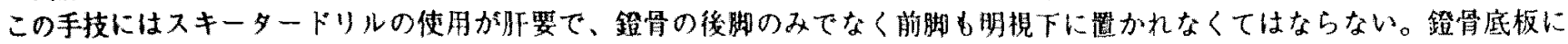
小孔を開けた佬、まず後脚を削除し、次いで前脚を削除する。レーザーの使用はさらにこの手技を容易なものとするかもしれ ない。绪は通常のstapedotomyと同样にテフロンビストンを小孔に入れて、砧骨艮脚に締結し終了する。症例はまだ 2 例にすぎ

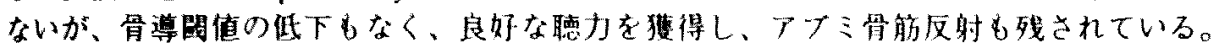

302 耳かき外傷による耳小骨損傷 11 例の病態と治療成績

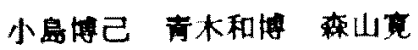

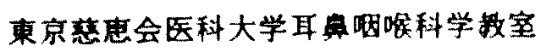

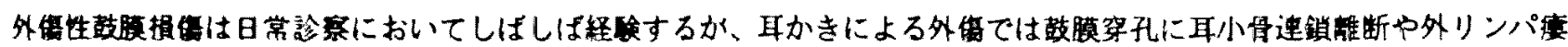

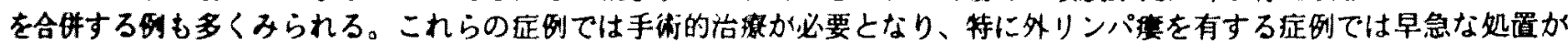

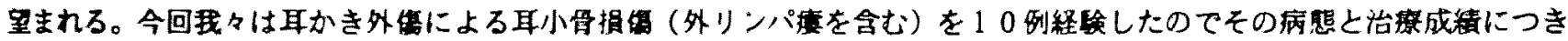

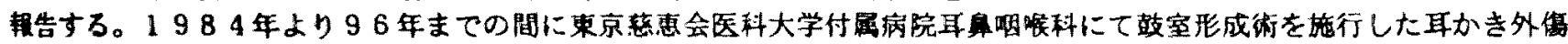

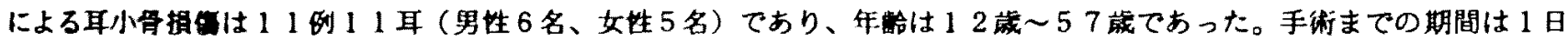

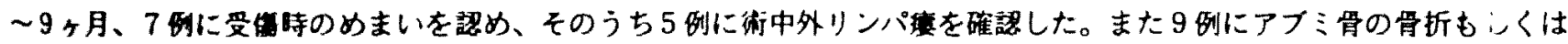

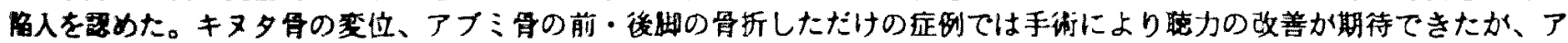
ブミ骨の焰入した列では衙後聴力の改善度が低い㑯向がられた。

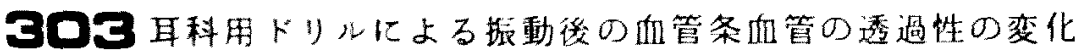

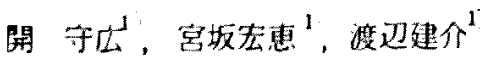

1)独坮医科大学越谷病院耳界咽喉科

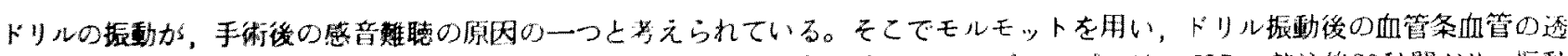

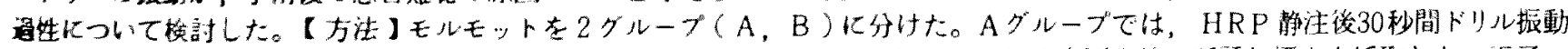

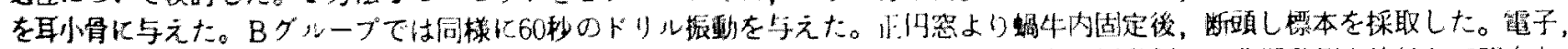

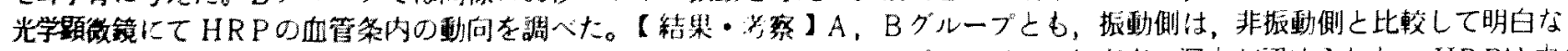

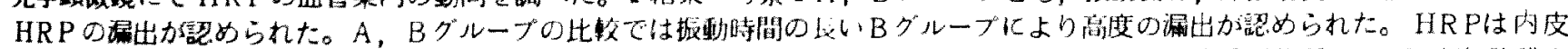

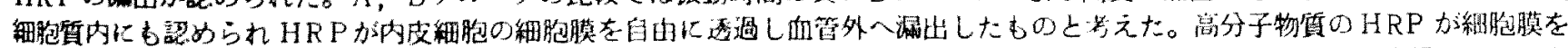

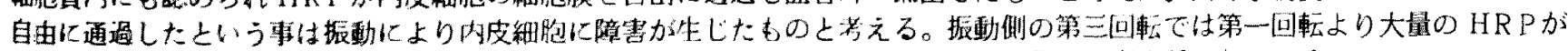

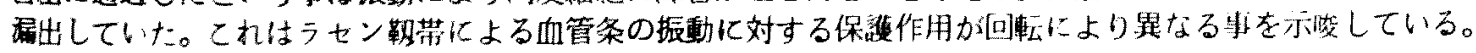

\title{
304 呼吸状慜加中耳圧に及ほす影震
}

五十装文旅

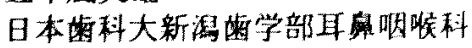

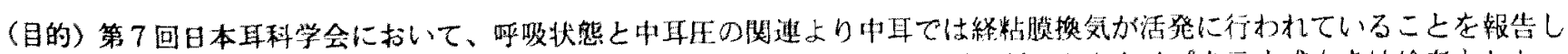

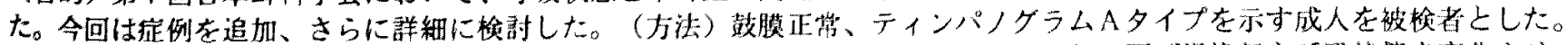

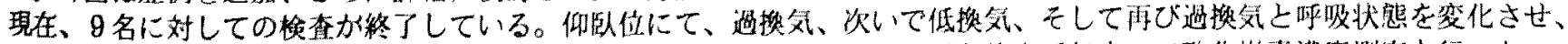

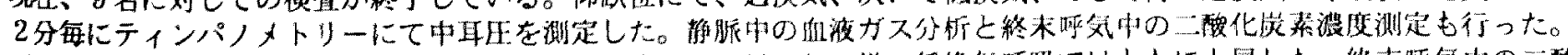

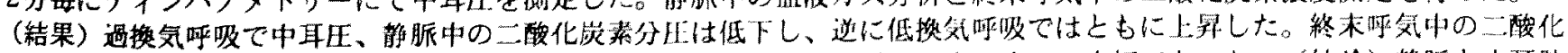

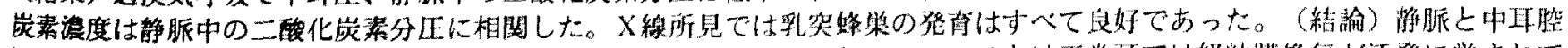

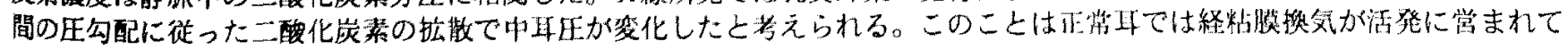
いることを示すものと思われる。 